\title{
Pengembangan Kewirausahaan bagi Mahasiswa Pembudidaya Jamur Tiram melalui Magang di CV Irvan Jamur Madiun
}

\author{
Agita Risma Nurhikmawati ${ }^{1)}$, Wachidatul Linda Yuhanna ${ }^{2)}$, Diyah Santi Hariyani ${ }^{3)}$, \\ Pujiati $^{4)}$, Davi Apriandi ${ }^{5)}$, Muhammad Nur Rony Sanjaya ${ }^{6)}$ \\ ${ }_{1,2,3,4,5,6)}$ Program Pengembangan Kewirausahaan (PPK) Universitas PGRI Madiun \\ 1)agitarnurhikmawati@unipma.ac.id, ${ }^{2)}$ linda.yuhanna@unipma.ac.id., \\ $\frac{{ }^{3)} \text { diyah.santi@unipma.ac.id., }{ }^{4)} \text { pujiati@unipma.ac.id., }{ }^{5)} \text { davi.mathedu@unipma.ac.id., }}{\text { nurrony763@ gmail.com }}$
}

\begin{abstract}
The development of the potential student entrepreneurship is one aspect of the vision and mission of the University of PGRI Madiun which is realized in various activities. The entrepreneurial potential of students coming from PKMK, PMW, KBMI, and student business ideas as a result of entrepreneurship courses, needs to be developed as an ongoing effort to form new innovative and competitive entrepreneurs. One of the business fields of students is Mushroom cultivation. The form of business strengthening by the Entrepreneurship Development Program team is an internship activity. This internship aims to know and understand directly about the process of cultivating Oyster Mushrooms. The apprenticeship is carried out from April 14 to May 12, 2018 at CV. Irfan Jamur, Kebonsari, Madiun. The material taught is preparation of tools and materials, baglog making, maintenance, and marketing. The products produced are baglog and fresh Mushroom. The results of the internship show that students have been able to make 500 baglogs without contamination. The result of internships is the experience and material relevant to students before starting a business and increasing the work ethic of students in entrepreneurship. Keywords: Entrepreneurship, Mushroom, Internship
\end{abstract}

\begin{abstract}
Abstrak
Pengembangan potensi kewirausahaan mahasiswa merupakan salah satu aspek dalam visi dan misi Universitas PGRI Madiun yang diwujudkan dalam berbagai kegiatan. Potensi kewirausahaan mahasiswa berasal dari PKMK, PMW, KBMI, dan proposal ide bisnis mahasiswa sebagai hasil dari mata kuliah kewirausahaan, perlu dikembangkan sebagai upaya keberlanjutan untuk membentuk wirausahawan baru yang inovatif dan kompetitif. Salah satu bidang usaha dari mahasiswa adalah budidaya Jamur Tiram. Bentuk penguatan bisnis oleh tim Program Pengembangan Kewirausahaan (PPK) adalah kegiatan magang. Magang ini bertujuan untuk mengetahui dan memahami secara langsung tentang proses pembudidayaan Jamur Tiram. Pelaksanaan magang dilakukan mulai tanggal 14 April sampai dengan 12 Mei 2018 di CV. Irfan Jamur, Kebonsari, Madiun. Materi yang diajarkan adalah persiapan alat dan bahan, pembuatan baglog, perawatan, dan pemasaran. Produk hasil produksi adalah
\end{abstract}


Jurnal Pengabdian pada Masyarakat

baglog dan Jamur Tiram segar. Hasil magang menunjukkan bahwa mahasiswa telah mampu membuat 500 baglog tanpa kontaminasi. Hasil dari magang PPK adalah adanya pengalaman dan materi yang relevan bagi mahasiswa sebelum memulai bisnis dan meningkatkan etos kerja mahasiswa dalam berwirausaha.

Kata Kunci : Kewirausahaan, Jamur Tiram, Magang.

\section{PENDAHULUAN}

Pengembangan potensi kewirausahaan mahasiswa merupakan salah satu aspek dalam visi dan misi Universitas PGRI Madiun yang diwujudkan dalam berbagai kegiatan. Potensi kewirausahaan mahasiswa berasal dari PKMK, PMW, KBMI, dan proposal ide bisnis mahasiswa sebagai hasil dari mata kuliah kewirausahaan perlu dikembangkan sebagai upaya keberlanjutan untuk membentuk wirausahawan baru yang inovatif dan kompetitif. Program pengembangan kewirausahaan Kampus (PPK) merupakan salah satu wadah dan dukungan untuk menghasilkan lulusan yang mempunyai daya saing. Program ini melibatkan tim dosen sebagai mentor, praktisi, dan mahasiswa (Budiyanto dan Rofieq, 2016; Masluri et.al, 2013).

Tema kewirausahaan yang menjadi fokus Universitas PGRI Madiun adalah industri kreatif, makanan dan minuman, produksi, budidaya, teknologi dan jasa. Bidang usaha budidaya yang dikembangkan oleh mahasiswa di Universitas PGRI Madiun adalah budidaya Jamur Tiram. Jamur Tiram (Pleurotus ostreatus) merupakan jamur yang banyak digemari oleh masyarakat. Selain kelezatannya, jamur tiram juga sangat bermanfaat bagi kesehatan tubuh. Kandungan gizinya yang tinggi dengan berbagai macam asam amino esensial yang terkandung di dalamnya, Jamur Tiram juga mengandung senyawa-senyawa lainnya yang penting bagi aspek medis. Jamur tiram mengandung 18 macam asam amino yang dibutuhkan oleh tubuh manusia dan tidak mengandung kolesterol. Jenis asam amino tersebut adalah isoleusin, lysin, methionin, cystein, penylalanin, tyrosin, treonin, tryptopan, valin, arginin, histidin, alanin, asam aspartat, asam glutamat, glysin, prolin dan serin. Komposisi dan kandungan nutrisi setiap 100 gram jamur tiram mengandung 367 kalori, 10.5-30.4\% protein, 56.6\% karbohidrat, $1.72 .2 \%$ lemak, $0.20 \mathrm{mg}$ thiamin, 4.7-4.9 mgriboflavin, .2 mg niacin, 314.0 mg kalsium (Widyastuti, 2008; Wiardani, 2010).

Pada masyarakat Jepang dan Cina, menu makanan yang terbuat dari jamur sudah menjadi menu yang turun temurun karena mengetahui khasiatnya yang sangat baik bagi tubuh. Di Indonesia, konsumsi jamur tiram dari tahun ke tahun diketahui semakin meningkat seiring dengan kebutuhan masyarakat akan produk pangan yang sehat dan terjangkau. Jamur tiram merupakan salah satu jamur yang banyak dijual di pasaran.

Bentuk tudungnya seperti cangkang tiram. Bagian tudung dari jamur tiram tersebut berubah warna dari hitam, abu-abu, coklat hingga putih dengan permukaan yang hampir licin yang bertepi tudung mulus sedikit berlekuk. Batang atau tangkai dari jamur tiram ini tidak berada pada tengah tudung, namun agak ke pinggir. Tubuh buah mempunyai tudung yang berubah dari putih menjadi krem dan semakin dewasa warna tudung akan semakin jelas. Di alam, jamur tiram hanya dijumpai pada musim 
Agita Risma Nurhikmawati, dkk.

tertentu dalam jumlah yang terbatas dan menumpuk pada batang pohon yang telah melapuk (Wiardani, 2010).

Pengembangan wirausaha kampus memerlukan suatu upaya pendampingan dan penguatan bisnis. Upaya yang dilakukan oleh tim Program Pengembangan Kewirausahaan (PPK) Universitas PGRI Madiun adalah dengan sistem ICE (Innovation and Competitive Entrepreneurship) yang terdiri dari kegiatan seleksi tenant, workshop start up bisnis, magang, pemberian modal usaha, pembimbingan proses produksi oleh mentor dan praktisi, pembimbingan pemasaran dan analisis biaya, pendampingan e-commerce, Focus Group Discussion (FGD), sarasehan bisnis dan pameran kewirausahaan. Program pengembangan kewirausahaan di kampus merupakan upaya dalam meningkatkan intensi kewirausahaan bagi mahasiswa (Sumarsono, 2016).

Magang kewirausahaan adalah upaya strategis dalam membelajarkan suatu bisnis. Resmi (2013) dan Triharyanto (2014) menyatakan bahwa proses belajar melalui magang dapat menumbuhkan dan membiasakan diri untuk mengikuti proses pekerjaan yang dilakukan oleh ahli secara langsung. Melalui proses belajar seperti ini secara tidak sadar pemagang selain memperoleh keterampilan, juga akan mengalami perubahan dalam pengetahuan dan sikap terutama sikap dalam menghadapi pekerjaan tersebut. Husen (2012), Sahulata (2012) dan Zainudin (2012) menyatakan bahwa Pemagangan dimaksudkan sebagai upaya melatih keterampilan baik dalam bidang produksi, manajemen usaha, distribusi, pemasaran, dan negosiasi. Selama peserta magang dilakukan monitoring rutin untuk mengevaluasi sejauh mana tingkat efektifitas dan efisiensi kerja dilapangan.

Magang Program Pengembangan Kewirausahaan (PPK) adalah untuk 1) Memberikan pengalaman dan materi yang cukup sebelum memulai bisnis, 2) Meningkatkan etos kerja mahasiswa dalam berwirausaha. 3) Mengetahui, mengenal, mengidentifikasi dan memecahkan permasalahan dalam bidang budidaya jamur tiram putih, pemasaran dan analisis bisnisnya.

Manfaat yang dapat diambil dari kegiatan magang ini yaitu untuk menambah pengetahuan dalam budidaya Jamur Tiram hingga cara memasarkannya dan untuk mengembangkan pengetahuan di bidang pembudidayaan Jamur Tiram guna memulai bisnis sendiri untuk mewujudkan wirausahawan muda yang mandiri.

\section{METODE}

Kegiatan magang PPK di bidang budidaya ini dilakukan di CV Irfan Jamur, Kebonsari Madiun. Waktu pelaksanaan magang adalah mulai tanggal 14 April 2018 sampai 12 Mei 2018. Jumlah tenant yang melakukan magang adalah 6 mahasiswa. Alokasi waktu pelaksanaan magang adalah selama 5 jam perhari. Praktisi pendamping adalah pemilik CV Irfan Jamur (Bapak Damirul Irfan, S.E). Materi yang diajarkan adalah persiapan alat dan bahan, pembuatan baglog, perawatan, dan pemasaran.

\section{HASIL DAN PEMBAHASAN}

Kegiatan magang merupakan kegiatan lanjutan dari workshop start up bisnis yang dilaksanakan di mitra pilihan sesuai dengan kapasitas usaha yang relevan. 
Mahasiswa dengan bidang usaha budidaya jamur tiram ini melaksanakan magang di CV Irfan Jamur, kebonsari Kabupaten madiun. CV Irfan Jamur dalam tiga tahun terakhir bergerak dalam produksi baglog jamur dan jamur segar siap konsumsi. CV Irfan jamur mampu memproduksi lebih dari 10.000 baglog jamur yang siap untuk dipasarkan. Sedangkan dalam sebulan, jamur segar yang dihasilkan kurang lebih 1000 kg. Mitra dari CV Irfan Jamur tersebar di berbagai daerah area Karesidenan Madiun. Sehingga mitra ini sangat relevan untuk tempat belajar mahasiswa calon wirausaha.

\section{Materi I Persiapan alat dan bahan}

Materi pertama yang disampaikan adalah persiapan alat dan bahan untuk membuat baglog Jamur Tiram. Pengenalan alat yang digunakan untuk budidaya jamur meliputi peralatan dasar, peralatan sterilisasi, peralatan fermentasi, peralatan produksi baglog dan peralatan perawatan Jamur Tiram. Peralatan dasar yang harus disediakan adalah rak jamur, dan ruangan steril. Alat yang digunakan untuk sterilisasi diantaranya adalah oven/drum steam, kompor gas, thermome. Alat yang digunakan untuk fermentasi adalah sekop, plastik terpal, ember, timbangan, dan pengayak. Alat yang digunakan dalam pembuatan baglog adalah plastik baglog (polipropilen), cincin baglog diameter $11 \times 2 \mathrm{~cm}$, karet gelang, kapas, dan kertas koran. Alat yang digunakan dalam perawatan jamur adalah penyemprot uap air.

Bahan yang digunakan dalam pembuatan baglog terdiri dari bahan utama dan bahan media tanam. Bahan utama yang digunakan adalah bibit F2 Jamur Tiram, alkohol, spiritus. Bahan yang digunakan untuk media antara lain serbuk gergaji, bekatul/dedak, kapur dolomit, gipsum, dan air. Media sangat penting dalam penyediaan nutrisi bagi bibit jamur. Hariadi et.al (2013), Suprapti (1988) dan Winarni dan Rahayu (2002) menyatakan bahwa substrat yang biasa digunakan adalah serbuk gergaji, jerami dan bekatul. Komposisi harus diatur agar menghasilkan baglog yang standar dan baik.

\section{Materi II Pembuatan Baglog}

Kegiatan magang ini secara umum dilakukan dengan metode praktik dan observasi. Mahasiswa peserta magang dilibatkan secara langsung dengan mengobservasi dan membuat baglog secara mandiri. Pembuatan baglog meliputi tahap pencampuran, pembuatan media, strerilisasi, inokulasi dan inkubasi. Tahap pencampuran bahan meliputi 1) Merendam serbuk gargaji selama 24 jam. 2) Meletakkan bahan pada tempat yang datar dan kering. 3) Mencampur komposisi bahan dengan perbandingan serbuk gergaji $100 \mathrm{~kg}$, bekatul/dedak15 kg, kapur dolomit/ kalsit $2 \mathrm{~kg}$, Plus $1 \mathrm{~kg}$, air 80-90 \%. 4) Mencampur komposisi bahan tersebut hingga homogen dan tidak menggumpal. 5) Mengecek kelembaban adukan bahan, apabila sudah lembab dihentikan. 6) Menutup adonan bahan dengan plastik terpal dan fermentasi selama 1 hari.

Tahap pembuatan media tanam meliputi 1) Menyiapkan alat dan bahan. 2) Memasukkan komposisi bahan ke dalam plastik baglog. 3) Memadatkan bahan yang dimasukkan dalam plastik hingga tidak ada ruang kosong menggunakn mesin pemadat bisa juga ditumbuk menggunakan botol kaca. 4) Memasang cincin baglog pada ujung plastik. 5) Membuat lubang pada tengah-tengah cincin dengan menggunakan kayu 
Agita Risma Nurhikmawati, dkk.

sedalan 3-4 cm. 6) Mengikat ujung plastik pada cincin jamur dengan karet gelang. 7) Menyumbat cincin jamur dengan kapas. 8) Menutup cincin jamur yang sudah disumbat dengan kapas menggunakan kertas koran dan mengikatnya dengan karet gelang.

Tahapan sterilisasi baglog meliputi 1) Memasukkan baglog pada oven/drum steam. 2) Mensterilisasi baglog pada suhu $114^{0} \mathrm{C}$ konstan selama 7-8 jam. 3) Mendinginkan baglog pada tempat yang steril. Tahapan inokulasi bibit jamur ke dalam baglog dan inkubasi pengamatan miselium meliputi 1) Mensterilkan telapak tangan dengan menggunakan alkohol 70\%. 2) Membuka plastik/ kertas yang menutup cincin jamur pada baglog. 3) Membuka sumbatan kapas pada cincin jamur. 4) Menginokulasikan bibit jamur tiram kurang lebih 4-5 butir bibit jamur ke dalam baglog menggunakan tongkat inokulasi. 5) Menutup kembali cincin baglog dengan kapas. 6) Mengingkubasikan baglog ke dalam ruang pembibitan. 7) Mengamati pertumbuhan miselium jamur dalam baglog.

\section{Materi III Perawatan}

Perawatan Jamur Tiram dilakukan dengan penyiraman secara periodik dan sortasi baglog yang kontaminasi. Pada proses perawatan jamur perlu memperhatikan syarat tumbuh. Syarat tumbuh jamur tiram yang baik antara lain kandungan air dalam substrat berkisar antara 60-65\%. Apabila kondisi kering maka pertumbuhan jamur akan terganggu atau terhenti, begitu pula sebaliknya apabila kadar air terlalu tinggi maka miselium akan membusuk dan mati. Penyempurnaan air dalam ruangan dapat dilakukan untuk mengatur suhu dan kelembaban (Widyastuti, 2008)

Suhu Inkubasi atau saat jamur tiram membentuk miselium dipertahankan antara 60-70\%. Suhu pada pembentukan tubuh buah berkisar antara 16-22 ${ }^{\circ}$ C. Keleudara selama masa pertumbuhan miselium $60-70 \%$. Kelembaban udara pada pertumbuhan badan buah $80-90 \%$. Pertumbuhan jamur tiram sangat peka terhadap cahaya secara langsung. Cahaya tidak langsung (cahaya pantul biasa \pm 50-15000 lux) bermanfaat dalam perangsangan awal terbentuknya tubuh buah. Intensitas cahaya yang dibutuhkan untuk pertumbuhan jamur sekitar 200 lux (10\%). Sedangkan pada pertumbuhan miselium tidak diperlukan cahaya.

Dua komponen penting dalam udara yang berpengaruh pada pertumbuhan jamur yaitu Oksigen $\left(\mathrm{O}_{2}\right)$ dan Karbon dioksida $\left(\mathrm{CO}_{2}\right)$. Oksigen merupakan unsur penting dalam respirasi sel. Sumber energi dalam sel dioksidasi menjadi karbondioksida. Konsentrasi Karbon dioksida $\left(\mathrm{CO}_{2}\right)$ yang terlalu banyak dalam kumbung menyebabkan pertumbuhan jamur tidak normal. Didalam kumbung jamur konsentrasi $\mathrm{CO}_{2}$ tidak boleh lebih dari $0,02 \%$.

Tingkat Keasaman $(\mathrm{pH})$ Tingkat keasaman media tanam mempengaruhi pertumbuhan dan petkembangan jamur tiram putih. Pada $\mathrm{pH}$ yang terlalu tinggi atau terlalu rendah akan mempengaruhi penyerapan air dan hara, bahkan kemungkinan akan tumbuh jamur yang lain yang akan menganggu pertumbuhan jamur tiram itu sendiri. pH optimum pada media tanam berkisar 6-7. Berdasarkan hasil praktik pembuatan 500 baglog oleh mahasiswa magang diperoleh hasil bahwa semua berhasil tanpa kontaminasi. 


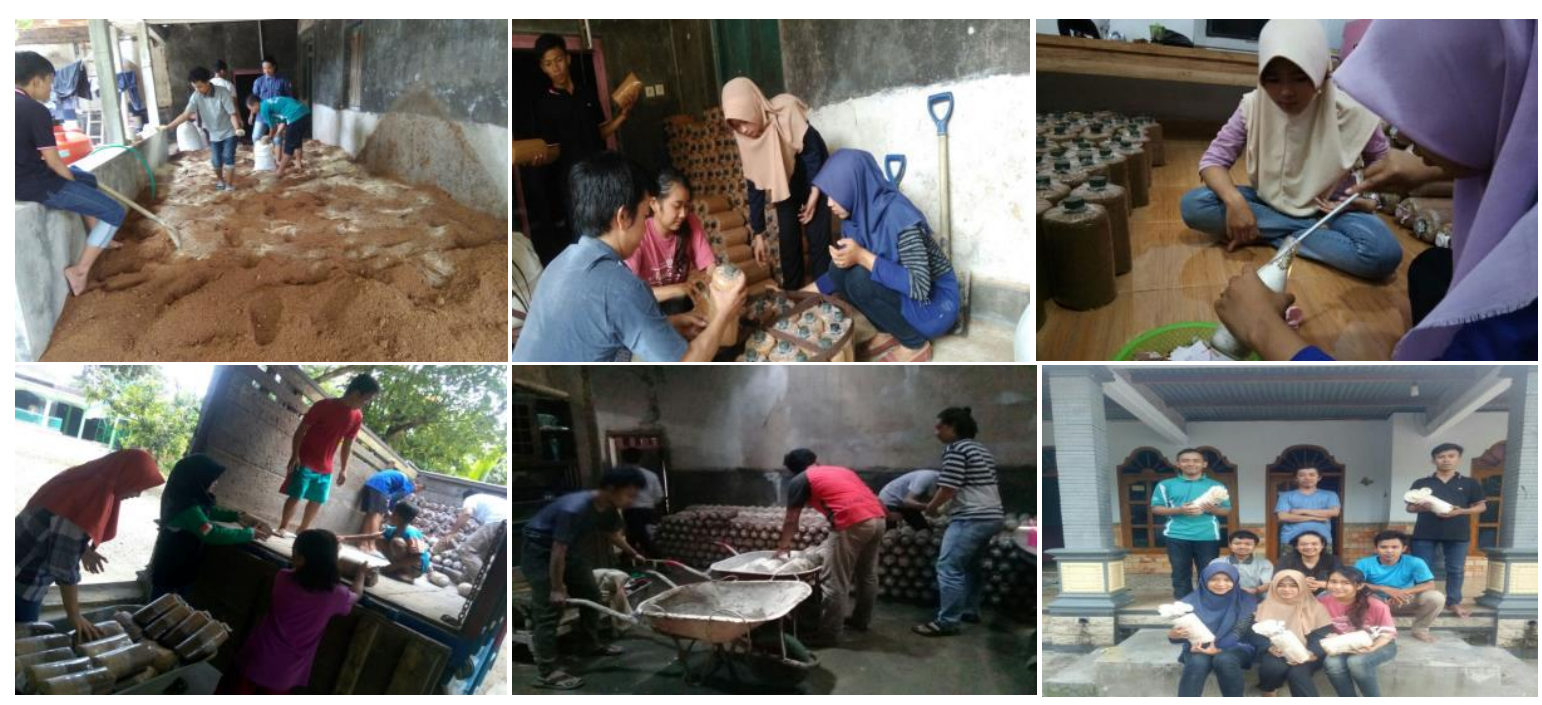

Gambar 1. Proses Pelaksanaan Magang PPK di CV. Irfan Jamur

\section{Materi IV Pemasaran Produk}

Produk hasil usaha CV Irfan Jamur adalah baglog dan jamur segar. Untuk baglog yang sudah siap dipasarkan, akan didistribusikan kepada mitra yaitu pembudidaya jamur tiram di area karesidenan Madiun sesuai dengan pesanan. Mahasiswa peserta magang diberi kesempatan untuk mengantar dan berkenalan dengan mitra dari CV Irfan Jamur, sehingga menambah wawasan dan membuka peluang pasar bagi mahasiswa yang akan melakukan wirausaha. Sinergi antar pembudidaya jamur tiram diperlukan sebagai bentuk penguatan usaha dan pemenuhan permintaan pasar. Jamur tiram segar dipasarkan pada tengkulak, pedagang sayur (mini pack) dan pemesan. Berdasarkan praktik dan arahan mentor praktisi tersebut, mahasiswa dapat mengetahui bagaimana cara memulai usaha budidaya Jamur Tiram mulai dari persiapan alat dan bahan hingga pemasaran dan analisis usaha. Rencana ke depan, setelah magang mahasiswa akan memulai start up bisnis dengan didampingi dari tim PPK universitas PGRI Madiun dan Praktisi dari CV Irfan Jamur.

\section{Simpulan}

\section{PENUTUP}

Kesimpulan dari kegiatan magang di CV Irfan Jamur ini adalah adanya magang ini memberikan pengalaman dan materi yang relevan bagi mahasiswa sebelum memulai bisnis dan meningkatkan etos kerja mahasiswa dalam berwirausaha.

\section{Saran}

Saran untuk kegiatan magang ini adalah perlu adanya berbagai materi tambahan seputar bagaimana mengatasi kendala dalam bidang pembibitan, produksi dan pemasaran lebih lanjut serta pengolahan produk Jamur Tiram. 
Agita Risma Nurhikmawati, dkk.

\section{Ucapan Terima Kasih}

Ucapan terimakasih kami sampaikan kepada 1) Kemenristekdikti yang telah memberikan dukungan finansial melalui Hibah PPK tahun 2018. 2) Bapak Damirul Irfan, SE selaku praktisi pendamping magang di CV. Irfan Jamur.

\section{DAFTAR PUSTAKA}

Budiyanto, H, Rofieq, M., "Menumbuh kembangkan Wirausaha Mahasiswa dan Alumni melalui Program IPTEK bagi Kewirausahaan di Universitas Merdeka Malang”. Jurnal pengabdian kepada masyarakat, 2017, 1.1.

Hariadi, N., Setyobudi, L., Nihayati, E. "Studi Pertumbuhan dan Hasil Produksi Jamur Tiram Putih (Pleorotus ostreatus) pada Media Tumbuh Jerami Padi dan Serbuk Gergaji”. Jurnal produksi tanaman, 2013, 1.1.

Husen, S. "Magang Kewirausahaan di Sentra Industri Pupuk Organik Azolla". Jurnal Dedikasi, 2012, 1.1.

Masluri, Nurkamid M., Sugiarto,.”Membentuk Wirausaha Baru melalui Program Ipteks Bagi Kewirausahaan (IbK) Di Universitas Muria Kudus”. Dianmas Vol. 2 No. 2, Oktober 2013, II (2).

Resmi, G.G."Membangun Jiwa Kewirausahaan melalui Kegiatan Pelatihan Kewirausahaan di Kalangan Mahasiswa (Sebuah Model Pelatihan Kewirausahaan di Kalangan Mahasiswa)”. Sustainable Competitive Advantage (SCA), 2013, 3.1.

Sahulata, W. "Program Magang Kerja Bidang Studi sebagai Upaya untuk Menumbuhkan Jiwa Wirausaha Mahasiswa Jurusan PKK". Prosiding APTEKINDO, 2012, 6.1.

Sumarsono, H. "Faktor-faktor yang Mempengaruhi Intensi Wirausaha Mahasiswa Universitas Muhammadiyah Ponorogo". Ekuilibrium: Jurnal Ilmiah Bidang Ilmu Ekonomi, 2016, 8.1: 62-88.

Suprapti, S. "Budidaya Jamur Perusak Kayu Pengaruh Penambahan Dedak terhadap Produksi Jamur Tiram”. Jurnal penelitian hasil hutan, 1988, 5.6: 337-339.

Triharyanto, E. "Pembentukan dan Pengembangan Calon Wirausaha Baru Melalui Pemagangan Usaha Tanaman Hias di Deni Nursery dan Gardening Karanganyar". IKB, 2014, 8.5.

Wiardani, I. “Budidaya Jamur Konsumsi” Penerbit Andi, 2010.

Widyastuti, netty. Aspek lingkungan sebagai faktor penentu keberhasilan budidaya jamur tiram (pleurotus sp). Jurnal teknologi Lingkungan, 2011, 9.3.

Winarni, I. Rahayu, U. "Pengaruh Formulasi Media Tanam dengan Bahan Dasar Serbuk Gergaji terhadap Produksi Jamur Tiram putih (Pleuratus ostreatus)". 2002.

Zainudin, A. "Magang Kewirausahaan di Sentra Produksi Apel Organik pada Kelompok Tani Apel Organik" AKAL". Jurnal Dedikasi, 2012, 2. 